\title{
A matrix isolation and flash photolysis study of the cyclization reactions of chromium amino carbenes
}

\author{
K.O. Doyle ${ }^{\mathrm{a}}$, M.L. Gallagher ${ }^{\mathrm{a}}$, M.T. Pryce ${ }^{\mathrm{b}}$, A.D. Rooney ${ }^{\mathrm{a}, *}$ \\ ${ }^{a}$ Department of Chemistry, National University of Ireland, Maynooth, Co. Kildare, Ireland \\ ${ }^{\mathrm{b}}$ School of Chemical Sciences, Dublin City University, Dublin, Ireland
}

Received 13 June 2000; accepted 11 September 2000

\begin{abstract}
The photochemistry of chromium amino carbene complexes have been studied using IR and UV-vis spectroscopy in matrices at $12 \mathrm{~K}$ and using UV-vis spectroscopy following laser flash photolysis in solution at room temperature (r.t.). The complexes studied can be divided into two classes. The Class 1 complexes are $(\mathrm{CO})_{5} \mathrm{Cr}\left[\mathrm{C}\left(\mathrm{NMe}_{2}\right) \mathrm{Me}\right],(\mathrm{CO})_{5} \mathrm{Cr}[\mathrm{C}(\mathrm{NBz}) \mathrm{Me}]$, $(\mathrm{CO})_{5} \mathrm{Cr}\left[\mathrm{C}\left(\mathrm{NMe}_{2}\right) \mathrm{Ph}\right]$ which are known to have a low or no photo-reactivity with imines to form $\beta$-lactams. Class 2 complexes are $(\mathrm{CO})_{5} \mathrm{Cr}\left[\mathrm{C}\left(\mathrm{NMe}_{2}\right) \mathrm{H}\right],(\mathrm{CO})_{5} \mathrm{Cr}\left[\mathrm{C}\left(\mathrm{NBz}_{2}\right) \mathrm{H}\right],(\mathrm{CO})_{5} \mathrm{Cr}\left[\mathrm{C}\left(\mathrm{NH}_{2}\right) \mathrm{Me}\right]$ and these complexes are known to undergo efficient photochemical reactions with imines to form $\beta$-lactams. The proposed active intermediate in the reaction to form $\beta$-lactams is a metal ketene complex. For both classes of complexes no ketene complex was observed upon irradiation in either the cryogenic matrix or the solution studies. The only photochemical process which was observed in all experiments was CO loss and the major product for all complexes was assigned to be cis- $(\mathrm{CO})_{4} \operatorname{Cr}\left[\left(\mathrm{N}\left(\mathrm{R}_{2}\right) \mathrm{R}^{\prime}\right]\right.$. This species behaved differently for the two classes of complexes. In the matrix isolation experiments on Class 2 complexes this species reacted with $\mathrm{N}_{2}$, ethene or CO present in the matrix cage, whereas for Class 1 complexes it did not. In the flash photolysis studies on Class 1 complexes the rate of reaction of this transient species with $\mathrm{CO}$ showed only a moderate dependence on the nature of the solvent. The rate of reaction for the same process measured for the transient species formed from Class 2 complexes showed a significantly greater dependence on the solvent. We propose that for Class 1 complexes the vacant site formed by photo-dissociation of a cis-CO ligand is blocked, whereas for the Class 2 complexes it is not. Therefore, in the latter case the site is open to reaction with active species in the cryogenic matrices and the solvent acts as a 'token' ligand in the solution studies. The difference in the reactivity of cis-(CO) ${ }_{4} \mathrm{Cr}\left[\mathrm{C}\left(\mathrm{NR}_{2}\right) \mathrm{R}^{\prime}\right]$ for the two classes of complex may aid the explanation of the differences in their synthetic photochemistry. (C) 2001 Elsevier Science B.V. All rights reserved.
\end{abstract}

Keywords: Chromium carbenes; Matrix isolation; Flash photolysis

\section{Introduction}

Chromium carbene complexes undergo a wide variety of thermal and photochemical reactions and have proven to be extremely useful synthons in organic chemistry [1]. For example, they are involved in a range of cyclisation reactions, and in the formation of $\alpha$ amino acids and esters [1-3]. One well-studied reaction of these complexes is the formation of $\beta$-lactams developed by Hegedus and co-workers [4]. This involves the photo-induced reaction of chromium carbenes with imines. The mechanism postulated for this reaction

* Corresponding author. Tel.: +353-1-7083770; fax: +353-17083815 . involves a chromium-ketene transient formed by the insertion of a cis carbon monoxide ligand into the $\mathrm{Cr}-$ Carbene bond upon promotion of the complex into the metal-to-ligand-charge-transfer (MLCT) excited state (Scheme 1) [1c]. The presence of the chromiumketene was inferred from studying the reaction conditions under which the carbenes resulted in the best yield of photo-product [5]. Moreover, studies comparing the photo-products of the carbenes and the thermal products of the analogous organic ketene with alkenes, dienes and imines showed that products were formed with a similar stereochemistry [6,7].

Previous spectroscopic studies have been carried out on carbene complexes in order to elucidate their primary photochemical steps. The work carried out on 
tungsten carbenes $\left((\mathrm{CO})_{5} \mathrm{~W}\left[\mathrm{C}(\mathrm{R}) \mathrm{R}^{\prime}\right]\right)$ has shown that these complexes have three low lying empty orbitals with symmetry labels $2 \mathrm{~b}_{1}, 2 \mathrm{a}_{1}$ and $3 \mathrm{a}_{1}$, respectively [8]. Transitions to each of these orbitals results in absorbances in the near UV-vis region. These are assigned as a MLCT band, a lower energy ligand field (LF) band and a high energy LF band. Irradiation into the high energy $\mathrm{LF}$ band of $(\mathrm{CO})_{5} \mathrm{~W}[\mathrm{C}(\mathrm{OMe}) \mathrm{Ph}]$ results in the dissociation of a cis $\mathrm{CO}$ ligand [9]. Irradiation into the low energy LF band would be expected to induce loss of the carbene or the trans CO ligand [10]. The main transformation that occurs upon MLCT excitation is the isomerisation from the anti to the syn isomer (Eq. (1)) [10-12].

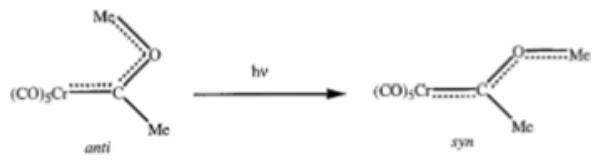

Previous work carried out by our group on the matrix photochemistry of chromium and tungsten alkoxy carbenes of the type $(\mathrm{CO})_{5} \mathrm{M}[\mathrm{C}(\mathrm{OMe}) \mathrm{Me}](\mathrm{M}=$ $\mathrm{Cr}, \mathrm{W})$ showed that there was no evidence for the formation of a ketene transient in cryogenic matrices held at $12 \mathrm{~K}$ [13]. However, the absence of a ketene transient could arise in a matrix at $12 \mathrm{~K}$ because there is a thermal barrier to its formation. The study showed that the tungsten carbene which does not form a $\beta$-lactam when irradiated in the presence of an imine was less active to both $\mathrm{CO}$ and carbene photo-induced dissociation in the matrices. Furthermore, it was shown that $\mathrm{CO}$ loss occurred from the chromium carbene at all irradiation wavelengths. At the time, using the assumption that CO loss only occurs upon population of
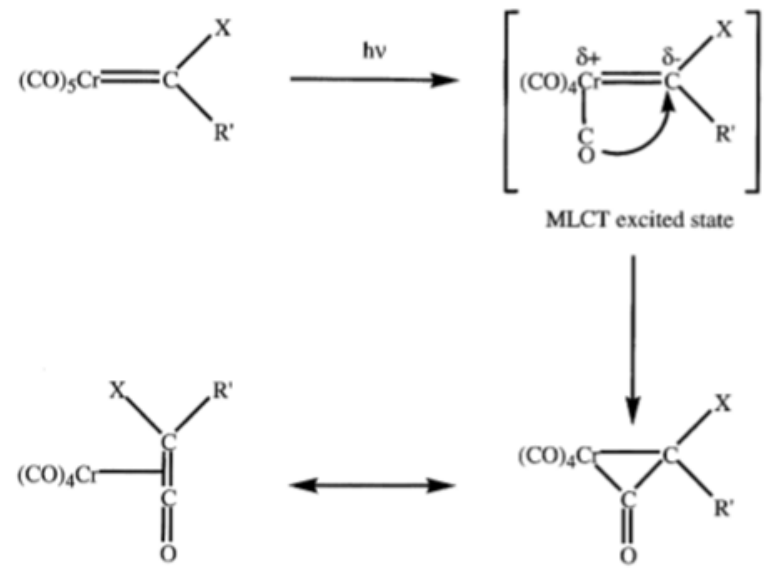

$\mathrm{X}=$ amino, alkoxy, $\mathrm{R}=$ alkyl, aryl, $\mathrm{H}$

Scheme 1. Proposed mechanism for the formation of a chromiumketene transient from promotion into the MLCT excited state of $(\mathrm{CO})_{5} \mathrm{Cr}[\mathrm{C}(\mathrm{X}) \mathrm{R}]$. a LF excited state, it was proposed that it is not possible to solely populate the MLCT state. It was suggested that the MLCT state may not be involved in the formation of $\beta$-lactam. However, calculations on related metal carbonyl systems have shown that $\mathrm{CO}$ loss can occur upon initial population of a low lying MLCT state $[14,15]$. The main disadvantage in working with complexes of the type $(\mathrm{CO})_{5} \mathrm{Cr}\left[\mathrm{C}(\mathrm{OR}) \mathrm{R}^{\prime}\right]$ is that they display anti-syn photo-isomerisation. This isomerisation results in a transient species in the flash photolysis and matrix isolation experiments that complicates the results. In order to simplify the experiment, the work outlined in this paper is on amino carbenes as their symmetry precludes this anti-syn isomerisation. These types of carbenes have been generally overlooked with respect to low temperature and transient spectroscopic studies with no matrix isolation studies and only one flash photolysis paper on $(\mathrm{CO})_{5} \mathrm{Cr}[\mathrm{Im}]$ (shown below) having appeared previously [16].<smiles>CC(C)=C=C1N(C)C=CN1C</smiles>

Of the many amino carbenes that have been utilised in photochemical reactions there is a wide variation in their chemical reactivity. Even a very modest alteration in the structure of the carbene ligand can result in a significant reduction in the yield of $\beta$-lactam formed. For example, $(\mathrm{CO})_{5} \mathrm{Cr}\left[\mathrm{C}\left(\mathrm{NMe}_{2}\right) \mathrm{H}\right]$ reacts with imine to form $\beta$-lactam in good yield; a $30-56 \%$ yield of the cis and trans isomers of the $\beta$-lactam were formed when this complex was irradiated in acetonitrile solution in the presence of the $N$-methylimine of benzaldehyde for $20 \mathrm{~h}$ [17]. However, $(\mathrm{CO})_{5} \mathrm{Cr}\left[\mathrm{C}\left(\mathrm{NMe}_{2}\right) \mathrm{Me}\right]$ does not produce $\beta$-lactam upon irradiation [18]. Hafner et al. undertook a detailed mechanistic study using ${ }^{53} \mathrm{Cr}$ NMR in order to gain an insight into the relative reactivity of a large range of chromium carbene complexes [18]. This study incorporated both alkoxy and amino carbenes and no general relationship between the chemical shift of the ${ }^{53} \mathrm{Cr}-\mathrm{NMR}$ signal and carbene reactivity was observed. However, it would appear that there is a correlation between the linewidth of the ${ }^{53} \mathrm{Cr}-\mathrm{NMR}$ signal and carbene activity.

In this paper we have studied the matrix isolation and flash photolysis spectroscopy of six amino carbenes. We have divided the complexes into two types (1) Class 1 complexes $(\mathrm{CO})_{5} \mathrm{Cr}\left[\mathrm{C}\left(\mathrm{NMe}_{2}\right) \mathrm{Me}\right],(\mathrm{CO})_{5} \mathrm{Cr}$ $\left[\mathrm{C}\left(\mathrm{NBz}_{2}\right) \mathrm{Me}\right],(\mathrm{CO})_{5} \mathrm{Cr}\left[\mathrm{C}\left(\mathrm{NMe}_{2}\right) \mathrm{Ph}\right]$ have no or low activity towards the formation of $\beta$-lactam. (2) Class 2 complexes are $(\mathrm{CO})_{5} \mathrm{Cr}\left[\mathrm{C}\left(\mathrm{NMe}_{2}\right) \mathrm{H}\right],(\mathrm{CO})_{5} \mathrm{Cr}\left[\mathrm{C}\left(\mathrm{NBz}_{2}\right)\right.$ $\mathrm{H}],(\mathrm{CO})_{5} \mathrm{Cr}\left[\mathrm{C}\left(\mathrm{NH}_{2}\right) \mathrm{Me}\right]$ which have a medium to high activity towards $\beta$-lactam formation [18]. 


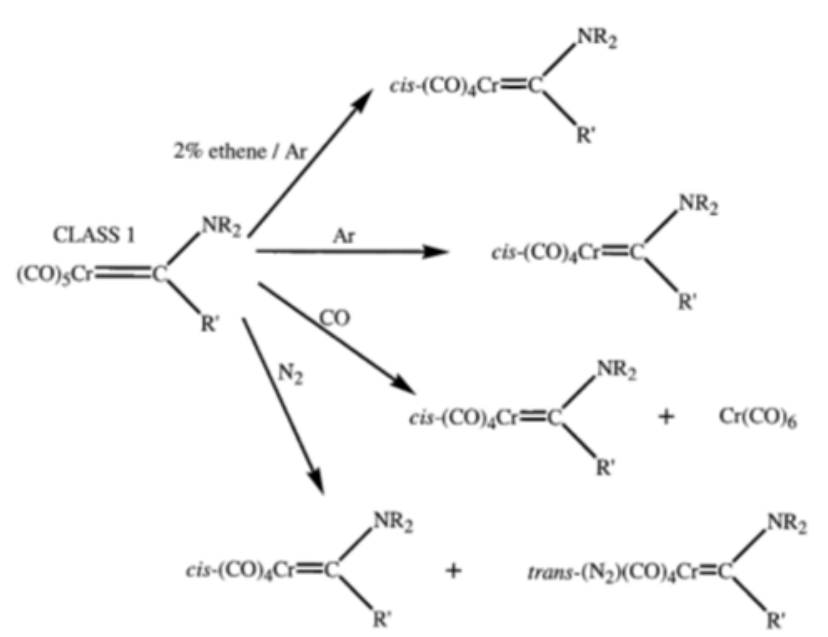

Scheme 2. Proposed assignment for species formed upon irradiation of Class 1 carbenes in cryogenic matrices.

\section{Results}

\subsection{Matrix isolation}

Summaries of the assignments given to the major products observed in the experiments on Classes 1 and 2 complexes in low temperature matrices are given in Schemes 2 and 3, respectively.

\subsubsection{Matrix isolation studies using IR spectroscopy}

2.1.1.1. Complexes of Class 1, $(\mathrm{CO})_{5} \mathrm{Cr}\left[\mathrm{C}\left(\mathrm{NMe}_{2}\right) \mathrm{Me}\right]$, $(\mathrm{CO})_{5} \mathrm{Cr}\left[\mathrm{C}\left(\mathrm{NBz}_{2}\right) \mathrm{Me}\right], \quad(\mathrm{CO})_{5} \mathrm{Cr}\left[\mathrm{C}\left(\mathrm{NMe}_{2}\right) \mathrm{Ph}\right]$ The $\mathrm{n}(\mathrm{CO})$ bands in the IR spectra of these complexes recorded upon deposition in argon matrices are given in Table 1. The IR spectra were recorded in the range $4000-400 \mathrm{~cm}^{-1}$ in all cases. Upon irradiation with
Table 1

$\mathrm{n}(\mathrm{CO})$ bands recorded in the IR spectra of $(\mathrm{CO})_{5} \mathrm{Cr}\left[\mathrm{C}\left(\mathrm{NR}_{2}\right) \mathrm{R}^{\prime}\right]$ upon irradiation in an argon matrix and after irradiation with light at II $320 \mathrm{~nm}$

\begin{tabular}{lll}
\hline Complex & $\begin{array}{l}\mathrm{n}(\mathrm{CO}) \text { in argon } \\
\left(\mathrm{cm}^{-1}\right)\end{array}$ & $\begin{array}{l}\mathrm{n}(\mathrm{CO}) \text { of cis- }(\mathrm{CO})_{4^{-}} \\
\mathrm{Cr}\left[\mathrm{C}\left(\mathrm{NR}_{2}\right) \mathrm{R}^{\prime}\right] \text { in } \\
\text { argon }\left(\mathrm{cm}^{-1}\right)\end{array}$ \\
\hline$(\mathrm{CO})_{5} \mathrm{Cr}\left[\mathrm{C}\left(\mathrm{NMe}_{2}\right) \mathrm{Me}\right]$ & $2060,1980,1935$ & $2029,1940,1925,1890$ \\
$(\mathrm{CO})_{5} \mathrm{Cr}\left[\mathrm{C}\left(\mathrm{NBz}_{2}\right) \mathrm{Me}\right]$ & $2060,1976,1941$ & $2029,1945,1924,1892$ \\
$(\mathrm{CO})_{5} \mathrm{Cr}\left[\mathrm{C}\left(\mathrm{NMe}_{2}\right) \mathrm{Ph}\right]$ & $2062,1980,1945$ & $2021^{\mathrm{a}}, 1921,1883$ \\
$(\mathrm{CO})_{5} \mathrm{Cr}\left[\mathrm{C}\left(\mathrm{NMe}_{2}\right) \mathrm{H}\right]$ & $2064,1980,1944$ & $2030,1940,1925,1883$ \\
$(\mathrm{CO})_{5} \mathrm{Cr}\left[\mathrm{C}\left(\mathrm{NBz}_{2}\right) \mathrm{H}\right]$ & $2064,1979,1940$ & $2037,2029(\mathrm{sh})^{\mathrm{a}}, 1902$ \\
$(\mathrm{CO})_{5} \mathrm{Cr}\left[\mathrm{C}\left(\mathrm{NH}_{2}\right) \mathrm{Me}\right]$ & $2065,1980,1953$, & $2037,2028(\mathrm{sh})^{\mathrm{a}}, 1900$ \\
& 1940 &
\end{tabular}

a Band obscured by starting material.

I $320 \mathrm{~nm}$ these complexes exhibit high photo-sensitivity to CO loss with greater than $50 \%$ depletion of the starting material as measured by the decrease in intensity of the high energy $n(C O)$ band after 10 min irradiation. It is possible that the $\mathrm{CO}$ can be lost from a cis or trans site on the chromium. Literature values show that cis- $(\mathrm{CO})_{4} \mathrm{Cr}[\mathrm{C}(\mathrm{X}) \mathrm{Y}]$ exhibits four $\mathrm{n}(\mathrm{CO})$ bands of high intensity, whereas the trans isomer exhibits only one band of high intensity and the other three are small or may not be detected $[9,19]$. The species observed is assigned as cis $-(\mathrm{CO})_{4} \mathrm{Cr}\left[\mathrm{C}\left(\mathrm{NR}_{2}\right) \mathrm{R}^{\prime}\right]$ which is consistent with published assignments (Table 1) $[10,19]$.

An IR spectrum of $(\mathrm{CO})_{5} \mathrm{Cr}\left[\mathrm{C}\left(\mathrm{NMe}_{2}\right) \mathrm{Me}\right]$ of the carbonyl stretching region is given in Fig. 1a along with the spectrum recorded after the matrix had being irradiated with I\ $320 \mathrm{~nm}$ for $30 \mathrm{~min}$ (Fig. 1(b)). No evidence for the formation of the ketene complex was observed. When the samples were irradiated in nitrogen

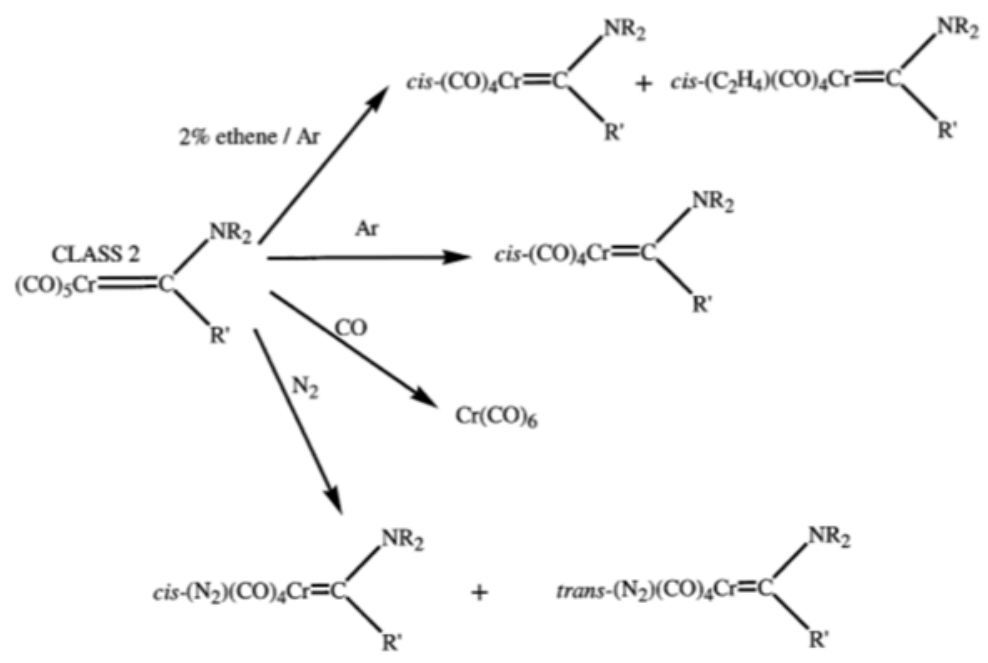

Scheme 3. Proposed assignment for species formed upon irradiation of Class 2 carbenes in cryogenic matrices. 
matrices CO loss occurred. The position of the high frequency $\mathrm{n}(\mathrm{CO})$ band of the $\mathrm{CO}$ loss species was essentially unchanged in wavenumber from the value observed for the respective complex irradiated in the argon matrix (Table 2). The spectra obtained were complicated by secondary photo-products when the complexes were irradiated in nitrogen matrices. These features will not be discussed in this paper. Irradiation of the matrices at I $\mid 320 \mathrm{~nm}$ produced one $\mathrm{n}\left(\mathrm{N}_{2}\right)$ band in the IR difference spectra of the three complexes; the band came at $2169 \mathrm{~cm}^{-1}$ for $(\mathrm{CO})_{5} \mathrm{Cr}\left[\mathrm{C}\left(\mathrm{NMe}_{2}\right) \mathrm{Me}\right]$, at $2173 \mathrm{~cm}^{-1}$ for $(\mathrm{CO})_{5} \mathrm{Cr}\left[\mathrm{C}\left(\mathrm{NBz}_{2}\right) \mathrm{Me}\right]$ (Fig. 2(a)), and at $2176 \mathrm{~cm}^{-1}$ for $(\mathrm{CO})_{5} \mathrm{Cr}\left[\mathrm{C}\left(\mathrm{NMe}_{2}\right) \mathrm{Ph}\right]$. Formation of the $\mathrm{n}\left(\mathrm{N}_{2}\right)$ band was not concomitant with the formation of the high energy $\mathrm{n}(\mathrm{CO})$ band which is assigned as arising from cis $-(\mathrm{CO})_{4} \mathrm{Cr}\left[\mathrm{C}\left(\mathrm{NR}_{2}\right) \mathrm{R}^{\prime}\right]$. Prolonged irradiation of $(\mathrm{CO})_{5} \mathrm{Cr}\left[\mathrm{C}\left(\mathrm{NMe}_{2}\right) \mathrm{Me}\right]$ for $3 \mathrm{~h}$ at $\mid \backslash 400 \mathrm{~nm}$ in a nitrogen matrix confirmed that the $\mathrm{n}\left(\mathrm{N}_{2}\right)$ band at 2169 $\mathrm{cm}^{-1}$ corresponds to a set of $\mathrm{n}(\mathrm{CO})$ bands at 1905 (intense), and $1860 \mathrm{~cm}^{-1}$ which, with reference to

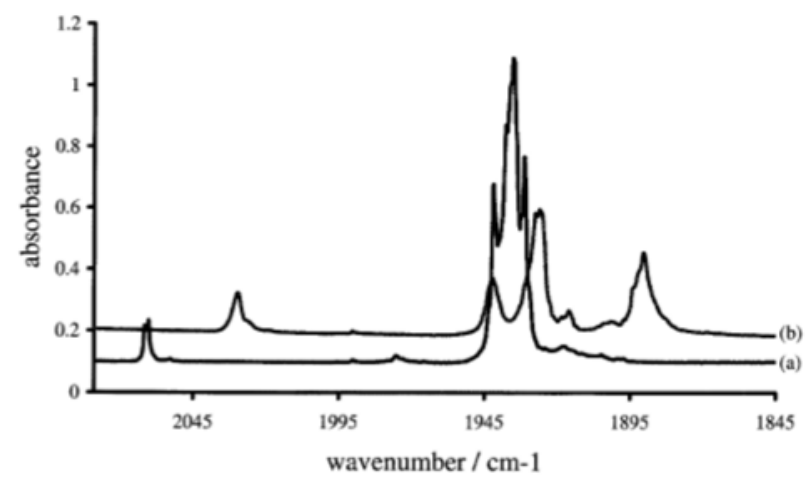

Fig. 1. IR spectra showing the carbonyl stretching region of (CO) ${ }_{5} \mathrm{Cr}\left[\mathrm{C}\left(\mathrm{NMe}_{2}\right) \mathrm{Me}\right]$ (a) upon deposition in an argon matrix (b) after $30 \mathrm{~min}$ irradiation with I $320 \mathrm{~nm}$.

Table 2

The major $n(C O)$ and $n\left(N_{2}\right)$ bands observed in the IR spectra of $(\mathrm{CO})_{5} \mathrm{Cr}\left[\mathrm{C}\left(\mathrm{NR}_{2}\right) \mathrm{R}^{\prime}\right]$ after irradiation with light at $\ \backslash 320 \mathrm{~nm}$ in a nitrogen matrix

\begin{tabular}{lll}
\hline Complex & $\begin{array}{l}\mathrm{n}(\mathrm{CO}) \text { in nitrogen } \\
\left(\mathrm{cm}^{-1}\right)\end{array}$ & $\begin{array}{l}\mathrm{n}\left(\mathrm{N}_{2}\right) \text { in nitrogen } \\
\left(\mathrm{cm}^{-1}\right)\end{array}$ \\
\hline$(\mathrm{CO})_{4} \mathrm{Cr}\left[\mathrm{C}\left(\mathrm{NMe}_{2}\right) \mathrm{Me}\right]$ & $\begin{array}{l}2028,2025(\mathrm{sh}), 1938, \\
1923,1888\end{array}$ & 2169 \\
& $\begin{array}{l}2028,2024(\mathrm{sh}), 1940, \\
(\mathrm{CO})_{4} \mathrm{Cr}\left[\mathrm{C}\left(\mathrm{NBz}_{2}\right) \mathrm{Me}\right]\end{array}$ & 2173 \\
& 1921,1889 & \\
$(\mathrm{CO})_{4} \mathrm{Cr}\left[\mathrm{C}\left(\mathrm{NMe}_{2}\right) \mathrm{Ph}\right]$ & $2020,1939,1917,1878$ & 2176 \\
$(\mathrm{CO})_{4} \mathrm{Cr}\left[\mathrm{C}\left(\mathrm{NMe}_{2}\right) \mathrm{H}\right]$ & $2025,1940,1927,1899$ & 2217,2176 \\
$(\mathrm{CO})_{4} \mathrm{Cr}\left[\mathrm{C}\left(\mathrm{NBz}_{2}\right) \mathrm{H}\right]$ & $2025^{\mathrm{a}}, 1931,1898$ & 2221,2176 \\
$(\mathrm{CO})_{4} \mathrm{Cr}\left[\mathrm{C}\left(\mathrm{NH}_{2}\right) \mathrm{Me}\right]$ & $2033,2026(\mathrm{sh})^{\mathrm{a}}, 1917$, & 2215,2186 \\
& 1892 &
\end{tabular}

\footnotetext{
a Band obscured by starting material.
}

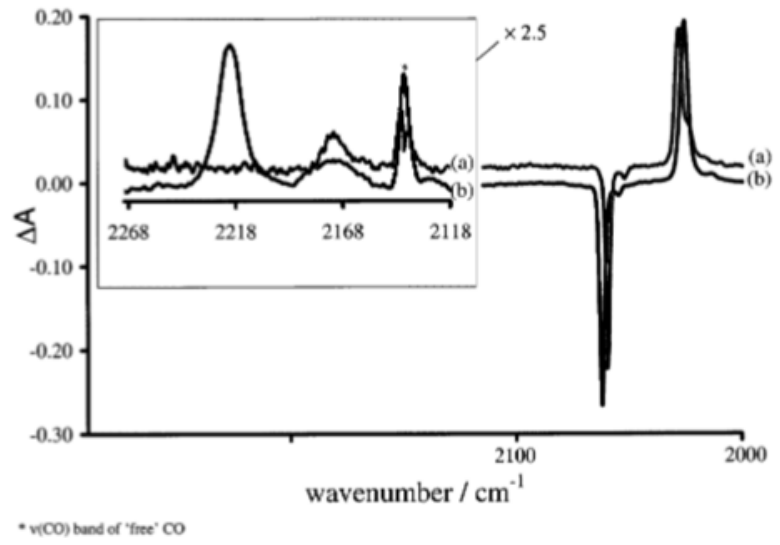

Fig. 2. IR difference spectra showing the $\mathrm{n}\left(\mathrm{N}_{2}\right)$ and high frequency $\mathrm{n}(\mathrm{CO})$ bands of (a) $(\mathrm{CO})_{5} \mathrm{Cr}\left[\mathrm{C}\left(\mathrm{NBz}_{2}\right) \mathrm{Me}\right]$ irradiated for $30 \mathrm{~min}$ with I $320 \mathrm{~nm}$ in a nitrogen matrix and; (b) $(\mathrm{CO})_{5} \mathrm{Cr}\left[\mathrm{C}\left(\mathrm{NBz}_{2}\right) \mathrm{H}\right]$ irradiated for $3 \mathrm{~h}$ with $\mid \backslash 320 \mathrm{~nm}$ in a nitrogen matrix. A difference spectrum is produced by subtracting the spectrum recorded upon deposition from that recorded after irradiation.

literature values, are assigned to the trans$(\mathrm{CO})_{4}\left(\mathrm{~N}_{2}\right) \mathrm{Cr}\left[\mathrm{C}\left(\mathrm{NMe}_{2}\right) \mathrm{Me}\right]$ isomer [19]. It is likely that a trans $\mathrm{CO}$ loss isomer also occurs upon irradiation of the complexes in the argon matrix experiments but is not observed in the IR spectrum as its bands overlap with those of the cis isomer. These experiments suggest that cis- $(\mathrm{CO})_{4} \mathrm{Cr}\left[\mathrm{C}\left(\mathrm{NMe}_{2}\right) \mathrm{Me}\right]$ does not react with nitrogen in the matrix. This proposal was further tested in a series of experiments in which the complex was irradiated in an argon matrix that was doped with $2 \%$ ethene. For all three complexes studied, the product bands formed were identical to those observed in the $100 \%$ argon matrix. Therefore the cis$(\mathrm{CO})_{4} \mathrm{Cr}\left[\mathrm{C}\left(\mathrm{NR}_{2}\right) \mathrm{R}^{\prime}\right]$ does not react with ethene in the matrix (Table 3). An IR difference spectrum recorded after irradiation of $(\mathrm{CO})_{5} \mathrm{Cr}\left[\mathrm{C}\left(\mathrm{NMe}_{2}\right) \mathrm{Ph}\right]$ in (a) a $100 \%$ argon and; (b) a $2 \%$ ethene-argon matrix is shown in Fig. 3.

2.1.1.2. Complexes of Class 2, $(\mathrm{CO})_{5} \mathrm{Cr}\left[\mathrm{C}\left(\mathrm{NMe}_{2}\right) \mathrm{H}\right]$, $(\mathrm{CO})_{5} \mathrm{Cr}\left[\mathrm{C}\left(\mathrm{NH}_{2}\right) \mathrm{Me}\right],(\mathrm{CO})_{5} \mathrm{Cr}\left[\mathrm{C}\left(\mathrm{NBz}_{2}\right) \mathrm{H}\right]$. The n(CO) bands recorded in the IR spectra of these complexes upon deposition in argon matrices are given in Table 1. Upon irradiation in argon matrices these complexes proved to be significantly less photosensitive than the Class 1 complexes. A depletion of greater than $40 \%$ of the starting material as measured by the decrease in the intensity of the high energy $\mathrm{n}(\mathrm{CO})$ band was recorded in all cases after $3 \mathrm{~h}$ irradiation at I $\mid 320 \mathrm{~nm}$. Again $\mathrm{CO}$ loss was the only photochemical process observed and the major product was the cis isomer. A further study on $(\mathrm{CO})_{5} \mathrm{Cr}\left[\mathrm{C}\left(\mathrm{NMe}_{2}\right) \mathrm{H}\right]$ showed that photo-induced $\mathrm{CO}$ loss could be detected when this sample was irradiated for $1 \mathrm{~h}$ in an argon matrix at II $375 \mathrm{~nm}$. Irradiation of these complexes in nitrogen matrices 
resulted in the formation of two $\mathrm{n}\left(\mathrm{N}_{2}\right)$ bands in the IR spectra recorded (Table 2), one close in wavenumber to the $\mathrm{n}\left(\mathrm{N}_{2}\right)$ band observed upon the irradiation of Class 1 complexes in nitrogen matrices, and one at a higher wavenumber. In the experiment carried out on $(\mathrm{CO})_{5} \mathrm{Cr}\left[\mathrm{C}\left(\mathrm{NMe}_{2}\right) \mathrm{H}\right]$ it was observed that upon prolonged irradiation the $\mathrm{n}\left(\mathrm{N}_{2}\right)$ band at $2217 \mathrm{~cm}^{-1}$ decreased in intensity concurrently with the $\mathrm{n}(\mathrm{CO})$ bands assigned to cis- $(\mathrm{CO})_{4} \mathrm{Cr}\left[\mathrm{C}\left(\mathrm{NMe}_{2}\right) \mathrm{H}\right]$. This suggests that in contrast to the behaviour of cis$(\mathrm{CO})_{4} \mathrm{Cr}\left[\mathrm{C}\left(\mathrm{NMe}_{2}\right) \mathrm{Me}\right]$ in a nitrogen matrix that a $\mathrm{N}_{2}$ molecule is occupying the vacant site formed upon $\mathrm{CO}$ photo-dissociation. An IR difference spectrum of $(\mathrm{CO})_{5} \mathrm{Cr}\left[\mathrm{C}\left(\mathrm{NBz}_{2}\right) \mathrm{H}\right]$ recorded upon irradiation in a nitrogen matrix is shown in Fig. 2(b). This shows that in contrast to Class 1 complexes, irradiation of Class 2 carbenes with I $320 \mathrm{~nm}$ yields two nitrogen adducts. The ability of alkenes to interact with the metal centre following photo-dissociation of a CO ligand was investigated using an argon matrix doped with $2 \%$ ethene. In addition to the species formed in a pure argon matrix a further species was formed, indicated by the presence of a $\mathrm{n}(\mathrm{CO})$ band at $2018 \mathrm{~cm}^{-1}$ for $(\mathrm{CO})_{5} \mathrm{Cr}\left[\mathrm{C}\left(\mathrm{NBz}_{2}\right) \mathrm{H}\right]$ and $(\mathrm{CO})_{5} \mathrm{Cr}\left[\mathrm{C}\left(\mathrm{NMe}_{2}\right) \mathrm{H}\right]$, and at $2024 \mathrm{~cm}^{-1}$ for

Table 3

High energy $\mathrm{n}(\mathrm{CO})$ bands observed in the IR spectra of $(\mathrm{CO})_{5} \mathrm{Cr}\left[\mathrm{C}\left(\mathrm{NR}_{2}\right) \mathrm{R}^{\prime}\right]$ after irradiation at $\backslash \backslash 320 \mathrm{~nm}$ in a $2 \%$ ethene-argon matrix doped and in an argon matrix

\begin{tabular}{lll}
\hline Complex & $\begin{array}{l}\text { High energy } \mathrm{n}(\mathrm{CO}) \\
\text { bands upon irradiation } \\
\text { in 2\% ethene-Ar } \\
\left(\mathrm{cm}^{-1}\right)\end{array}$ & $\begin{array}{l}\text { High energy } \mathrm{n}(\mathrm{CO}) \\
\text { bands upon } \\
\text { irradiation in } \mathrm{Ar} \\
\left(\mathrm{cm}^{-1}\right)\end{array}$ \\
\hline$(\mathrm{CO})_{5} \mathrm{Cr}\left[\mathrm{C}\left(\mathrm{NMe}_{2}\right) \mathrm{Me}\right]$ & 2028 & 2029 \\
$(\mathrm{CO})_{5} \mathrm{Cr}\left[\mathrm{C}\left(\mathrm{NBz}_{2}\right) \mathrm{Me}\right]$ & 2028 & 2029 \\
$(\mathrm{CO})_{5} \mathrm{Cr}\left[\mathrm{C}\left(\mathrm{NMe}_{2}\right) \mathrm{Ph}\right]$ & 2020 & 2021 \\
$(\mathrm{CO})_{5} \mathrm{Cr}\left[\mathrm{C}\left(\mathrm{NMe}_{2}\right) \mathrm{H}\right]$ & 2029,2018 & 2030 \\
$(\mathrm{CO})_{5} \mathrm{Cr}\left[\mathrm{C}\left(\mathrm{NBz}_{2}\right) \mathrm{H}\right]$ & 2029,2018 & $2037,2029(\mathrm{sh})$ \\
$(\mathrm{CO})_{5} \mathrm{Cr}\left[\mathrm{C}\left(\mathrm{NH}_{2}\right) \mathrm{Me}\right]$ & 2037,2024 & $2037,2028(\mathrm{sh})$ \\
\hline
\end{tabular}

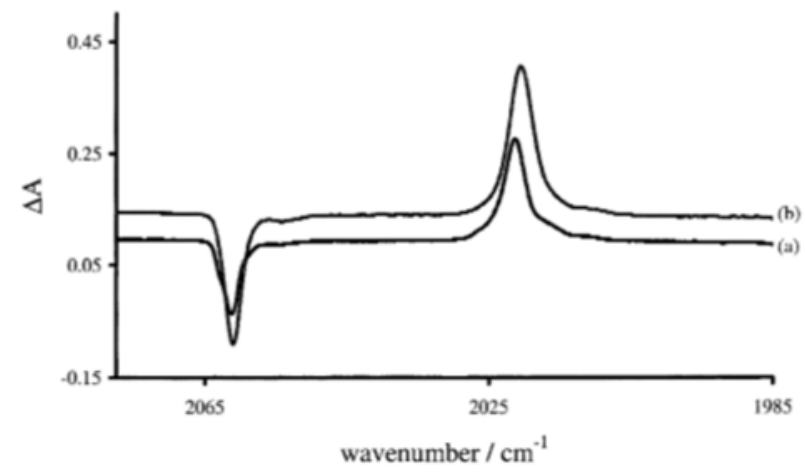

Fig. 3. IR difference spectra showing the high frequency $n(\mathrm{CO})$ bands of $(\mathrm{CO})_{5} \mathrm{Cr}\left[\mathrm{C}\left(\mathrm{NMe}_{2}\right) \mathrm{Ph}\right]$ after irradiation at I $320 \mathrm{~nm}$ (a) for 45 min in an argon matrix and (b) for $1 \mathrm{~h}$ in a $2 \%$ ethene-argon matrix.

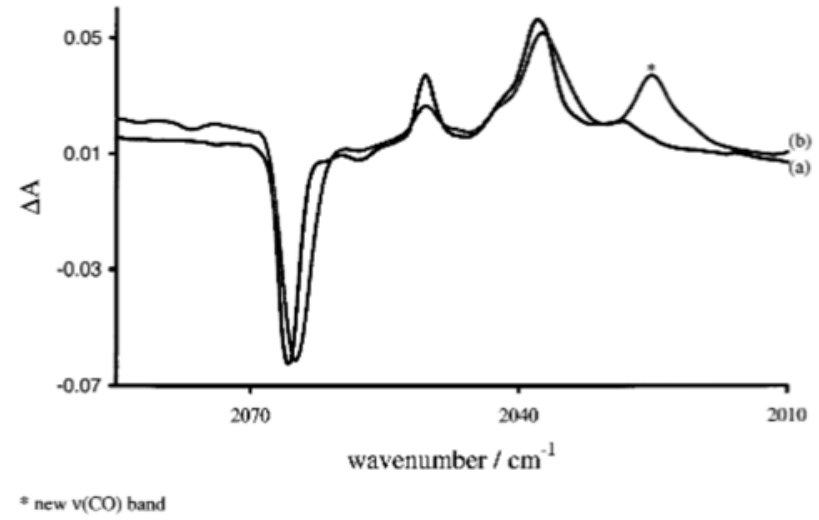

Fig. 4. IR difference spectra showing the high frequency $n(\mathrm{CO})$ bands of $(\mathrm{CO})_{5} \mathrm{Cr}\left[\mathrm{C}\left(\mathrm{NH}_{2}\right) \mathrm{Me}\right]$ after irradiation with $\mid \backslash 320 \mathrm{~nm}$ (a) for $1 \mathrm{~h}$ in an argon matrix and (b) for $1 \mathrm{~h}$ in a $2 \%$ ethene-argon matrix.

(CO) ${ }_{5} \mathrm{Cr}\left[\mathrm{C}\left(\mathrm{NH}_{2}\right) \mathrm{Me}\right]$ (Table 3). An IR difference spectrum recorded after irradiation of $(\mathrm{CO})_{5} \mathrm{Cr}\left[\mathrm{C}\left(\mathrm{NBz}_{2}\right) \mathrm{H}\right]$ in (a) a $100 \%$ argon and; (b) a $2 \%$ ethene-argon matrix is shown in Fig. 4. This indicates that the ethene is able to coordinate to the metal centre for Class 2 complexes but not for Class 1 .

The IR spectra of both Class 1 and Class 2 complexes recorded upon irradiation at I $\mid 320 \mathrm{~nm}$ in $\mathrm{Ar}$ matrices doped with 1-2\% CO exhibit a band at 1984 $\mathrm{cm}^{-1}$ which is assigned as the $\mathrm{n}(\mathrm{CO})$ of $\mathrm{Cr}(\mathrm{CO})_{6}$, indicating that the carbene ligand was dissociated. No bands were observed in the IR spectra that could be assigned to the carbene fragment. However, these bands will be of very low intensity compared to the $\mathrm{n}(\mathrm{CO})$ band of $\mathrm{Cr}(\mathrm{CO})_{6}$. Moreover, it may be that the carbene fragment is destroyed as matrix isolation studies on organic alkoxy alkyl carbenes have shown that they undergo photo-decomposition at the irradiation wavelengths used here [20]. Also we observed no bands in the IR spectra which could be assigned to a ketene compound. This would be the product of an organic carbene reacting with $\mathrm{CO}$ in the matrix. The $\mathrm{n}(\mathrm{CCO})$ band of a ketene comes at $2100-2200 \mathrm{~cm}^{-1}$ so it may be masked by the very intense $n(C O)$ band of the CO.

\subsubsection{Matrix isolation using $U V$-vis spectroscopy}

As flash photolysis utilises UV-vis spectroscopy to detect the transient species, the experiments outlined here were carried out to ensure that the same species was being studied in the cryogenic matrices and in the r.t. solution experiments. Moreover, we wanted to investigate whether it was possible to form photo-induced $\mathrm{CO}$ loss species in $\mathrm{CO}$ matrices. It is very difficult to study metal carbonyl complexes using IR spectroscopy in a $\mathrm{CO}$ matrix, as there is an extremely intense band at $2140 \mathrm{~cm}^{-1}$ due to the $\mathrm{n}(\mathrm{CO})$ of uncoordinated CO. Therefore UV-vis spectroscopy is a more convenient technique to use in these experiments. 
2.1.2.1. Complexes of Class 1, $(\mathrm{CO})_{5} \mathrm{Cr}\left[\mathrm{C}\left(\mathrm{NMe}_{2}\right) \mathrm{Me}\right]$, $(\mathrm{CO})_{5} \mathrm{Cr}\left[\mathrm{C}\left(\mathrm{NBz}_{2}\right) \mathrm{Me}\right],(\mathrm{CO})_{5} \mathrm{Cr}\left[\mathrm{C}\left(\mathrm{NMe}_{2}\right) \mathrm{Ph}\right]$. The spectral features of UV-vis spectra are generally broad and give little structural data. Therefore the assignment of the UV-vis spectra recorded upon irradiation of the complexes in matrices to $\mathrm{CO}$ loss species is taken from the observations made in the experiments with IR detection recorded under similar conditions. However, the changes in UV-vis spectra recorded between the carbene and the product formed upon irradiation are similar to those of the stable $\mathrm{CO}$ loss carbene complex $(\mathrm{CO})_{4}\left(\mathrm{CH}_{3} \mathrm{CN}\right) \mathrm{W}[\mathrm{C}(\mathrm{OMe}) \mathrm{Ph}]$ and its parent complex $(\mathrm{CO})_{5} \mathrm{~W}[\mathrm{C}(\mathrm{OMe}) \mathrm{Ph}][9]$. The UV-vis spectra recorded upon irradiation of these complexes with II $320 \mathrm{~nm}$ in $\mathrm{CO}$ matrices were very similar to those recorded when the complexes were irradiated in argon matrices. Moreover, for each carbene the spectrum recorded in the matrix was very similar to the transient UV-vis spectrum recorded in the room temperature flash photolysis experiments. These permit the results obtained in the low-temperature matrices to be correlated with those obtained in room temperature solution studies. Fig. 5 shows the UV-vis spectrum for $(\mathrm{CO})_{5} \mathrm{Cr}\left[\mathrm{C}\left(\mathrm{NMe}_{2}\right) \mathrm{Me}\right]$ recorded upon deposition and irradiation with II 320 $\mathrm{nm}$ in (a) an argon matrix and (b) a CO matrix. The

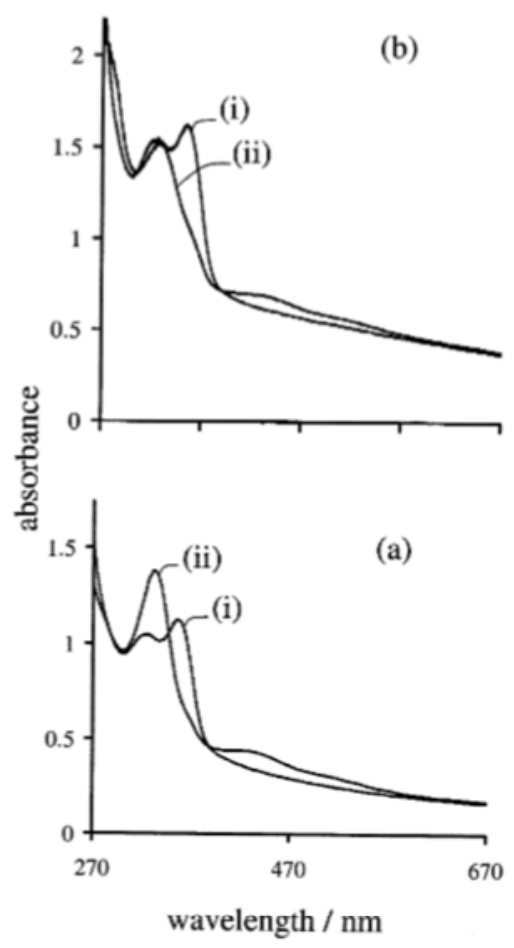

Fig. 5. (a) UV-vis spectra of $(\mathrm{CO})_{5} \mathrm{Cr}\left[\mathrm{C}\left(\mathrm{NMe}_{2}\right) \mathrm{Me}\right]$ in an argon matrix (i) upon deposition (ii) after $30 \mathrm{~min}$ irradiation with II 320 nm. (b) UV-vis spectra of $(\mathrm{CO})_{5} \mathrm{Cr}\left[\mathrm{C}\left(\mathrm{NMe}_{2}\right) \mathrm{Me}\right]$ in a $\mathrm{CO}$ matrix (i) upon deposition (ii) after 30 min irradiation with \ $320 \mathrm{~nm}$. fact that a CO loss transient can be detected in a $100 \%$ $\mathrm{CO}$ matrix indicates that the chromium has a low affinity for recombining with the $\mathrm{CO}$, and suggests that the vacant site may be blocked. A band was also recorded in the UV-vis spectra of the complexes upon irradiation at $\ \backslash 320 \mathrm{~nm}$ in a $\mathrm{CO}$ matrix which is assigned to $\mathrm{Cr}(\mathrm{CO})_{6}$.

2.1.2.2. Complexes of Class 2, $(\mathrm{CO})_{5} \mathrm{Cr}\left[\mathrm{C}\left(\mathrm{NMe}_{2}\right) \mathrm{H}\right]$, $(\mathrm{CO})_{5} \mathrm{Cr}\left[\mathrm{C}\left(\mathrm{NH}_{2}\right) \mathrm{Me}\right],(\mathrm{CO})_{5} \mathrm{Cr}\left[\mathrm{C}\left(\mathrm{NBz}_{2}\right) \mathrm{H}\right]$. The species observed upon irradiation of these complexes at II $320 \mathrm{~nm}$ in argon matrices exhibited a UV-vis spectrum in which the intense band at ca. $360 \mathrm{~nm}$ was shifted only slightly upwards in wavelength and the lower energy band was of low intensity. Irradiation of these complexes in $\mathrm{CO}$ matrices did not produce the same species that was recorded upon irradiation in the argon matrices. The complex either formed $\mathrm{Cr}(\mathrm{CO})_{6}$ or showed little photo-sensitivity. These observations would suggest that there is facile recombination of the transient with the $\mathrm{CO}$ ligand for these complexes. The $\mathrm{UV}$-vis spectrum of $(\mathrm{CO})_{5} \mathrm{Cr}\left[\mathrm{C}\left(\mathrm{NMe}_{2}\right) \mathrm{H}\right]$ recorded upon deposition and irradiation in (a) argon and; (b) $\mathrm{CO}$ matrices is shown in Fig. 6.

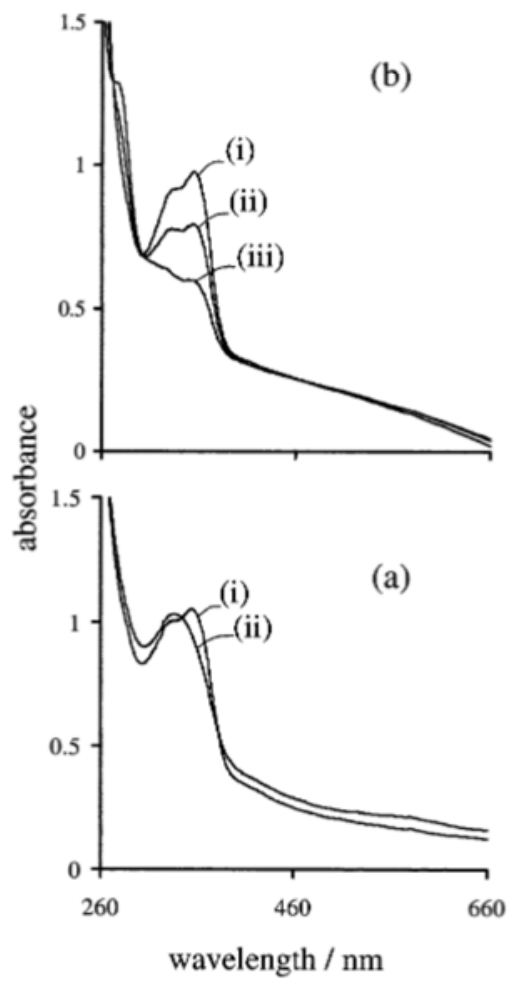

Fig. 6. (a) $\mathrm{UV}$-vis spectra of $(\mathrm{CO})_{5} \mathrm{Cr}\left[\mathrm{C}\left(\mathrm{NMe}_{2}\right) \mathrm{H}\right]$ in an argon matrix (i) upon deposition (ii) after $3.5 \mathrm{~h}$ irradiation with II $320 \mathrm{~nm}$. (b) $\mathrm{UV}$-vis spectra of $(\mathrm{CO})_{5} \mathrm{Cr}\left[\mathrm{C}\left(\mathrm{NMe}_{2}\right) \mathrm{H}\right]$ in a $\mathrm{CO}$ matrix (i) upon deposition (ii) after $1 \mathrm{~h}$ irradiation with $\mid \backslash 320 \mathrm{~nm}$ (iii) after $3.5 \mathrm{~h}$ irradiation with I\ $320 \mathrm{~nm}$. 
Table 4

Influence of solvent on observed rate constants for the reaction of the transient species generated by flash photolysis $\left(I_{\mathrm{exc}}=355 \mathrm{~nm}\right)$ of $(\mathrm{CO})_{5} \mathrm{Cr}\left[\mathrm{C}\left(\mathrm{NMe}_{2}\right) \mathrm{Me}\right]\left[2 \times 10^{-4} \mathrm{~mol} \mathrm{dm}^{-3}\right]$ with carbon monoxide under one atmosphere of carbon monoxide and under one atmosphere of argon

\begin{tabular}{lll}
\hline Solvent & $\begin{array}{l}\text { First order rate constant } \\
\left(\text { under one atm CO) }{ }^{\mathrm{a}}\right. \\
\left(\mathrm{s}^{-1}\right)\end{array}$ & $\begin{array}{l}\text { Observed rate constant } \\
(\text { under one atm Ar) }\end{array}$ \\
& $\begin{array}{l}\mathrm{b} \\
\left(\mathrm{s}^{-1}\right)\end{array}$ \\
\hline $\begin{array}{l}\text { Cyclohexane } \\
\text { Toluene }\end{array}$ & $\begin{array}{l}4.5 \times 10^{4} \\
1.8 \times 10^{4}\end{array}$ \\
$\begin{array}{l}\text { Acetone } \\
\text { THF }\end{array}$ & $\begin{array}{l}4.6 \times 10^{3} \\
4.4 \times 10^{3}\end{array}$ \\
Methanol & $1.5 \times 10^{3}$ & 92 \\
\hline
\end{tabular}

a Rate constants are accurate to $910 \%$

${ }^{\mathrm{b}}$ Rate constants are accurate to $920 \% . k_{\text {observed }}=k_{2} \mathrm{~d}$ where $\mathrm{o}=$ extinction coefficient of the transient and $l=$ length of the flash photolysis cell.

\section{2. $U V$-vis flash photolysis}

\subsubsection{Complexes of Class 1, $(\mathrm{CO})_{5} \mathrm{Cr}\left[\mathrm{C}\left(\mathrm{NMe}_{2}\right) \mathrm{Me}\right]$,} $(\mathrm{CO})_{5} \mathrm{Cr}\left[\mathrm{C}\left(\mathrm{NBz}_{2}\right) \mathrm{Me}\right],(\mathrm{CO})_{5} \mathrm{Cr}\left[\mathrm{C}\left(\mathrm{NMe}_{2}\right) \mathrm{Ph}\right]$

Upon irradiation of $(\mathrm{CO})_{5} \mathrm{Cr}\left[\mathrm{C}\left(\mathrm{NMe}_{2}\right) \mathrm{Me}\right]$ in solution with a laser excitation of $355 \mathrm{~nm}$ a single transient species was produced. The rate constant for the decay of this transient was quenched upon the addition of $\mathrm{CO}$ to the solvent (Table 4). The rate of decay of the transient was moderately solvent dependent and had a lower dependence than has previously been observed with $(\mathrm{CO})_{5} \mathrm{Cr}(\mathrm{S})(\mathrm{S}=$ solvent $)$. The pseudo-first order rate constant for the reaction of $(\mathrm{CO})_{5} \mathrm{Cr}(\mathrm{S})$ with $\mathrm{CO}$ under one atmosphere of $\mathrm{CO}$ is $2.8 \times 10^{4} \mathrm{~s}^{-1}$ in cyclohexane and $5.3 \times 10^{7} \mathrm{~s}^{-1}$ in $\mathrm{C}_{7} \mathrm{~F}_{14}[21,22]$. The low dependence of the rate of decay of the transient on the nature of the solvent was even more marked for the transients formed upon irradiation of $(\mathrm{CO})_{5} \mathrm{Cr}$ $\left[\mathrm{C}\left(\mathrm{NBz}_{2}\right) \mathrm{Me}\right]$ and $(\mathrm{CO})_{5} \mathrm{Cr}\left[\mathrm{C}\left(\mathrm{NMe}_{2}\right) \mathrm{Ph}\right]$ (Table 5). A second order rate constant for the reaction of $(\mathrm{CO})_{4} \mathrm{Cr}\left[\mathrm{C}\left(\mathrm{NMe}_{2}\right) \mathrm{Me}\right]$ with $\mathrm{CO}$ in cyclohexane was determined from the graph shown in Fig. 7 to be $(5.59$ 2.2) $\times 10^{6} \mathrm{dm}^{3} \mathrm{~mol}^{-1} \mathrm{~s}^{-1}$. This compares well with the second order rate constant for the reaction of $(\mathrm{CO})_{5} \mathrm{Cr}$ (cyclohexane) with $\mathrm{CO}$ in cyclohexane solution which has previously been determined to be $3.6 \times 10^{6}$ $\mathrm{dm}^{3} \mathrm{~mol}^{-1} \mathrm{~s}^{-1}$ (CO pressure 1.3 bar) [23].

An absorbance difference spectrum for the transient formed upon photo-induced $\mathrm{CO}$ loss from $(\mathrm{CO})_{5} \mathrm{Cr}$ $\left[\mathrm{C}\left(\mathrm{NMe}_{2}\right) \mathrm{Me}\right]$ taken at different time delays in cyclohexane solvent under an atmosphere of $\mathrm{CO}$ is given in

Table 5

Comparison of the influence of solvent on observed rate constants for the reaction of transient generated by flash photolysis from class one complexes $(\mathrm{CO})_{5} \mathrm{Cr}\left[\mathrm{C}\left(\mathrm{NMe}_{2}\right) \mathrm{Me}\right],(\mathrm{CO})_{5} \mathrm{Cr}\left[\mathrm{C}\left(\mathrm{NBz}_{2}\right) \mathrm{Me}\right]$ and $(\mathrm{CO})_{5} \mathrm{Cr}\left[\mathrm{C}\left(\mathrm{NMe}_{2}\right) \mathrm{Ph}\right]\left[2 \times 10^{-4}\right.$ mol dm $\left.^{-3}\right]$ with carbon monoxide under one atmosphere of carbon monoxide

\begin{tabular}{llll}
\hline & $\begin{array}{l}(\mathrm{CO})_{5} \mathrm{Cr}\left[\mathrm{C}\left(\mathrm{NMe}_{2}\right) \mathrm{Me}\right] \text { first order rate } \\
\text { constant }\left(\mathrm{s}^{-1}\right)^{\mathrm{a}}\end{array}$ & $\begin{array}{l}(\mathrm{CO})_{5} \mathrm{Cr}\left[\mathrm{C}\left(\mathrm{NBz}_{2}\right) \mathrm{Me}\right] \text { first order rate } \\
\text { constant }\left(\mathrm{s}^{-1}\right)\end{array}$ & $\begin{array}{l}(\mathrm{CO})_{5} \mathrm{Cr}[\mathrm{C}(\mathrm{NMe}) \mathrm{Ph}] \text { first order rate } \\
\text { constant }\left(\mathrm{s}^{-1}\right)\end{array}$ \\
\hline $\mathrm{C}_{7} \mathrm{~F}_{14}$ & $1.0 \times 10^{5}$ & $1.0 \times 10^{4}$ & $7.7 \times 10^{5}$ \\
Cyclohexane & $4.5 \times 10^{4}$ & $5.1 \times 10^{3}$ & $3.6 \times 10^{5}$ \\
Ethanol & $1.8 \times 10^{3}$ & $1.4 \times 10^{3}$ & $3.8 \times 10^{4}$ \\
\hline
\end{tabular}

${ }^{\text {a }}$ Rate constants are accurate to $910 \%$.

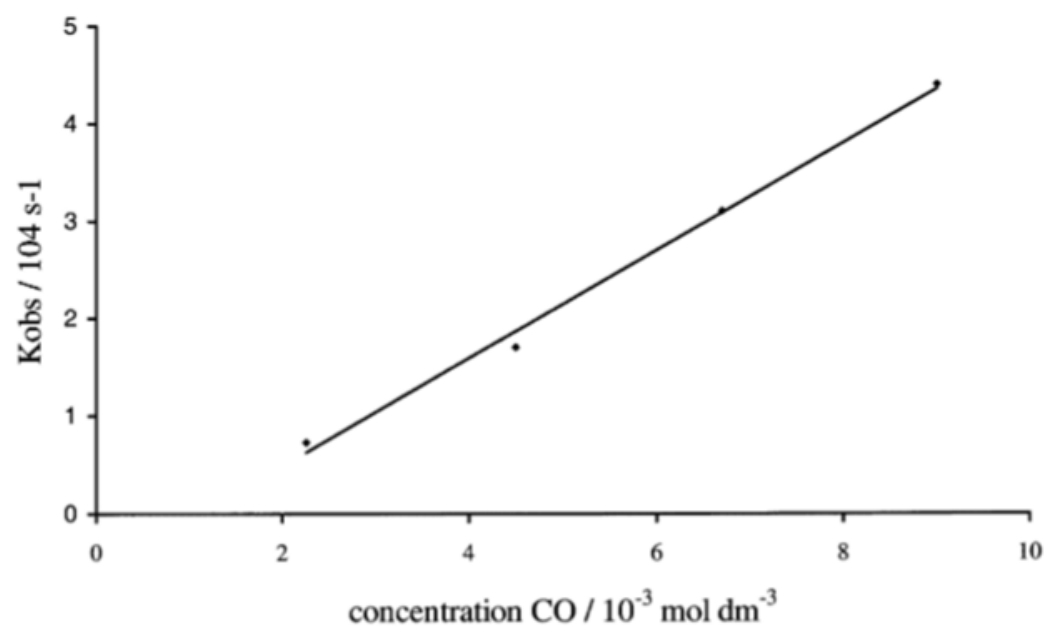

Fig. 7. Plot of the pseudo-first-order rate constants for the reaction of $(\mathrm{CO})_{4} \mathrm{Cr}\left[\mathrm{C}\left(\mathrm{NMe}_{2}\right) \mathrm{Me}\right]$ with $\mathrm{CO}$ versus the concentration of added $\mathrm{CO}$ measured at $460 \mathrm{~nm}$ in cyclohexane. The slope of the curve gives the second order rate constant for the reaction. 
Fig. 8(b). The similarity of this absorbance difference spectrum to that recorded upon irradiation of the same complex in an argon matrix (Fig. 8(a)) confirms that the photo-product is the same in both media. The $I_{\max }$ of the visible band of the transient species is insensitive to solvent polarity occuring at approximately $450 \mathrm{~nm}$ in all solvents studied. This is in contrast to the $I_{\max }$ of the visible band of transient species such as $(\mathrm{CO})_{5} \mathrm{CrS}$ or $(\mathrm{CO})_{4} \mathrm{SCr}[\mathrm{Im}]$ ( $\mathrm{S}=$ solvent) which is significantly affected by the nature of the solvent $[23-25,16]$.

\subsubsection{Complexes of Class $2(\mathrm{CO})_{5} \mathrm{Cr}\left[\mathrm{C}\left(\mathrm{NMe}_{2}\right) \mathrm{H}\right]$, $(\mathrm{CO})_{5} \mathrm{Cr}\left[\mathrm{C}\left(\mathrm{NH}_{2}\right) \mathrm{Me}\right],(\mathrm{CO})_{5} \mathrm{Cr}\left[\mathrm{C}\left(\mathrm{NBz}_{2}\right) \mathrm{H}\right]$}

Pulse photolysis of these complexes with $\mathrm{I}_{\mathrm{exc}}=355$ $\mathrm{nm}$ produced a single transient with a $\mathrm{I}_{\max }$ in the 400 $\mathrm{nm}$ range in nearly all solvents studied. Added $\mathrm{CO}$ quenched the lifetime of the transient. However, the rate constants for the reactions of these transients with $\mathrm{CO}$ were significantly more dependent on the nature of the solvent than those of Class 1. A summary of the rate constants for the reaction of the transients with $\mathrm{CO}$ in a range of solvents is given in Table 6 . The intensity of the absorbance band in the range $380-500 \mathrm{~nm}$ for the transient species formed from all Class 2 complexes showed a dependence on solvent being smaller in less polar solvents. For example, the absorbance difference spectra of the transient $(\mathrm{CO})_{4} \mathrm{Cr}\left[\mathrm{C}\left(\mathrm{NMe}_{2}\right) \mathrm{H}\right]$ recorded an intensity for this band at $\mathrm{I}_{\max }$ of $0.02 \mathrm{~A}$ (when the transient was measured under $0.2 \mathrm{~atm} \mathrm{CO} / 0.8 \mathrm{~atm} \mathrm{Ar}$, at $440 \mathrm{~nm}$ ) and of $0.12 \mathrm{~A}$ in ethanol (under one atm $\mathrm{Ar}$, at $420 \mathrm{~nm}$ ). This corresponds well with the results from the matrix experiments on these complexes. In non-polar argon matrices the intensity of the low energy band in the UV-vis spectra of the photo-induced species was low. Also the position of the high-energy band was little shifted from the starting material and so will be masked in the flash photolysis experiment which is based on absorbance differences. The absorbance difference spectra of the transient formed from the methyl analogue showed a much smaller solvent dependency. The low energy band had an intensity at I max of $0.1 \mathrm{~A}$ in cyclohexane (under one atm $\mathrm{CO}$, at $460 \mathrm{~nm}$ ) and of $0.15 \mathrm{~A}$ in ethanol (under one atm $\mathrm{CO}$, at $460 \mathrm{~nm}$ ).

For $(\mathrm{CO})_{5} \mathrm{Cr}\left[\mathrm{C}\left(\mathrm{NMe}_{2}\right) \mathrm{H}\right]$ and $(\mathrm{CO})_{5} \mathrm{Cr}\left[\mathrm{C}\left(\mathrm{NH}_{2}\right) \mathrm{Me}\right]$, a small second transient species with an absorbance at approximately $620 \mathrm{~nm}$ was observed when the complexes were irradiated in cyclohexane.

\section{Discussion}

The transient species detected upon irradiation of all the amino carbenes studied in both cryogenic matrices and in room temperature solution are assigned to $\mathrm{CO}$ loss species. Moreover, the matrix isolation study on the synthetically active complex $(\mathrm{CO})_{5} \mathrm{Cr}\left[\mathrm{C}\left(\mathrm{NMe}_{2}\right) \mathrm{H}\right]$ shows that photo-induced $\mathrm{CO}$ loss occurs even when the sample is irradiated into the low energy side of the MLCT band (I I $375 \mathrm{~nm}$ ). Absorbances of unassigned transient species were observed with a $I_{\max }$ at approximately $620 \mathrm{~nm}$ upon irradiation of $(\mathrm{CO})_{5} \mathrm{Cr}$ $\left[\mathrm{C}\left(\mathrm{NMe}_{2}\right) \mathrm{H}\right]$ and $(\mathrm{CO})_{5} \mathrm{Cr}\left[\mathrm{C}\left(\mathrm{NH}_{2}\right) \mathrm{Me}\right]$ in cyclohexane at $355 \mathrm{~nm}$ in the flash photolysis experiment. Detailed analysis of these transients was hindered by their low intensity but we suggest that they may arise from the unsolvated species $(\mathrm{CO})_{4} \mathrm{Cr}\left[\mathrm{C}\left(\mathrm{NR}_{2}\right) \mathrm{R}^{\prime}\right]$ by analogy with the study on $(\mathrm{CO})_{5} \mathrm{Cr}[\mathrm{Im}][16]$. These transients were not present when the experiment was repeated on the two complexes dissolved in the more coordinating solvents. Previous work by Hegedus and co-workers has shown that $(\mathrm{CO})_{5} \mathrm{Cr}\left[\mathrm{C}\left(\mathrm{NMe}_{2}\right) \mathrm{H}\right]$ only forms $\beta$-lactam when the complex is reacted with an imine in the coordinating solvent acetontrile [17]. Therefore, it is likely that these transients are not involved in the synthetic photochemistry of these complexes. We observed no transient that we can assign to a ketene species in the matrix or flash experiments and this indicates that this species is not a primary photochemical product. The $\mathrm{n}(\mathrm{CCO})$ bands of free or very weakly
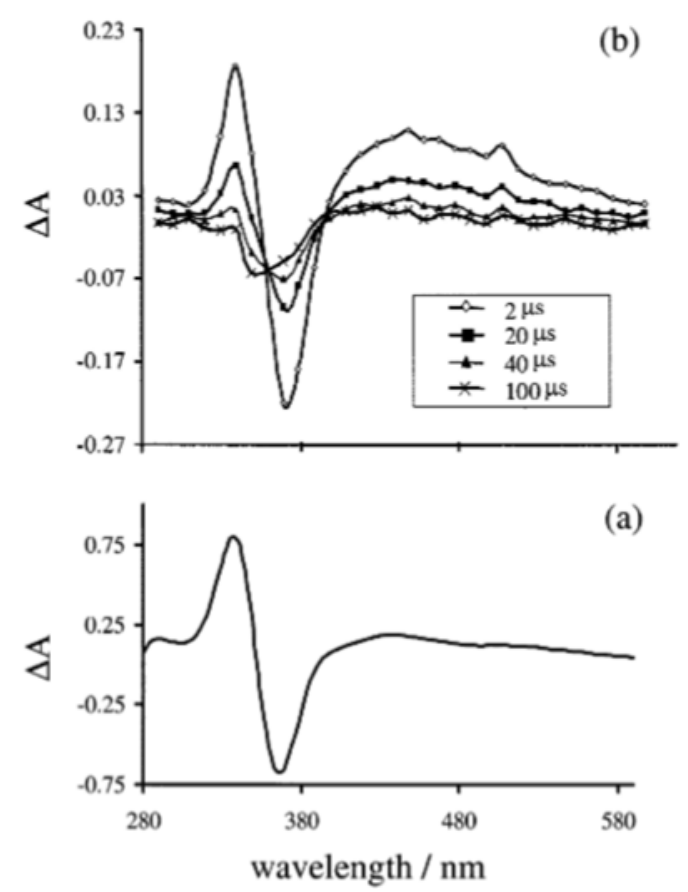

Fig. 8. (a) Absorbance difference spectrum of $(\mathrm{CO})_{5} \mathrm{Cr}\left[\mathrm{C}\left(\mathrm{NMe}_{2}\right) \mathrm{Me}\right]$ after $30 \mathrm{~min}$ irradiation with $\mid \backslash 320 \mathrm{~nm}$ in an argon matrix. (b) Transient absorbance difference $(\Delta \mathrm{A})$ spectra recorded at different time delays following flash photolysis at $355 \mathrm{~nm}$ of (CO) ${ }_{5} \mathrm{Cr}\left[\mathrm{C}\left(\mathrm{NMe}_{2}\right) \mathrm{Me}\right]$ in a $\mathrm{CO}$ saturated cyclohexane solution. The absorbance difference was measured point-by-point every $10 \mathrm{~nm}$. 
Table 6

Comparison of the influence of solvent on observed rate constants for the reaction of transient generated by flash photolysis from class two complexes $(\mathrm{CO})_{5} \mathrm{Cr}\left[\mathrm{C}\left(\mathrm{NMe}_{2}\right) \mathrm{H}\right],(\mathrm{CO})_{5} \mathrm{Cr}\left[\mathrm{C}\left(\mathrm{NBz}_{2}\right) \mathrm{H}\right]$, and $(\mathrm{CO})_{5} \mathrm{Cr}\left[\mathrm{C}\left(\mathrm{NH}_{2}\right) \mathrm{Me}\right]\left[2 \times 10^{-4}\right.$ mol dm $\left.{ }^{-3}\right]$ with carbon monoxide under one atmosphere of carbon monoxide

\begin{tabular}{llll}
\hline & $\begin{array}{l}(\mathrm{CO})_{5} \mathrm{Cr}\left[\mathrm{C}\left(\mathrm{NMe}_{2}\right) \mathrm{H}\right] \text { first order rate } \\
\text { constant }\left(\mathrm{s}^{-1}\right)^{\mathrm{a}}\end{array}$ & $\begin{array}{l}(\mathrm{CO})_{5} \mathrm{Cr}\left[\mathrm{C}\left(\mathrm{NBz}_{2}\right) \mathrm{H}\right] \text { first order rate } \\
\text { constant }\left(\mathrm{s}^{-1}\right)^{\mathrm{a}}\end{array}$ & $\begin{array}{l}\left.(\mathrm{CO})_{5} \mathrm{Cr}\left[\mathrm{C}(\mathrm{NH})_{2}\right) \mathrm{Me}\right] \text { first order rate } \\
\text { constant }\left(\mathrm{s}^{-1}\right)^{\mathrm{a}}\end{array}$ \\
\hline $\begin{array}{l}\text { Cyclohexane } \\
\text { Toluene }\end{array}$ & $\mathrm{b}$ & $3.0 \times 10^{4}$ & $\mathrm{~b}$ \\
Ethanol & $1.4 \times 10^{5}$ & $5.0 \times 10^{3}$ & $2.5 \times 10^{3}$ \\
ca. 6 & ca. 7 & ca. 6
\end{tabular}

${ }^{\text {a }}$ Rate constants are accurate to $910 \%$.

${ }^{\mathrm{b}}$ Signal too small to be analysed.

coordinated ketenes come in the range of 2100-2200 $\mathrm{cm}^{-1}$ and those of $\left(\eta^{2}\right.$-ketene) metal complexes in the range $1600-1800 \mathrm{~cm}^{-1}$ [26]. The only new band observed in these regions of the IR spectra of the complexes studied here is assigned to uncoordinated $\mathrm{CO}$ that has a $\mathrm{n}(\mathrm{CO})$ at $2140 \mathrm{~cm}^{-1}$. New bands were observed in the IR spectra in the region 1950-2100 $\mathrm{cm}^{-1}$ that would be consistent with a $\eta^{1}$-ketenyl complex. However, upon taking all the $\mathrm{n}(\mathrm{CO})$ bands in the spectra into consideration and by comparison with literature data we assigned these bands as arising from CO loss species $[9,10,13,19]$. As the only process detected in all experiments is photo-induced CO loss, our findings also suggest that this is the first step in the synthetic photochemistry of the amino carbenes. However, we do appreciate that any detailed mechanism would have to reconcile a $\mathrm{CO}$ dissociation mechanism with the experimental observation that the reaction to form $\beta$-lactam does take place when these chromium amino carbenes are irradiated in the presence of an imine under moderate pressures of CO (60 psi) [27].

The matrix experiments clearly show that the Class 1 complexes are more active with regards to photo-induced CO loss. If CO loss is an important step in the photochemistry of these complexes it is surprising that they are inactive to the formation of $\beta$-lactam or form it in low yield. However, our matrix studies indicate that the vacant site formed upon $\mathrm{CO}$ loss in these complexes is blocked. This is shown in the case of the $2 \%$ ethene-Ar matrix experiments in which the bands observed in the IR spectrum are identical to those of the analogous complex irradiated in an argon matrix. This indicates that, upon CO loss from the parent carbene, there are no matrix sites in which the ethene interacts with the chromium centre. However, when the same experiment was carried out on the Class 2 complexes, upon irradiation new bands were observed in the IR spectrum, suggesting in some sites ethene was interacting with the chromium. Moreover, using UVvis spectroscopy it was shown that when complexes of Class 1 were irradiated in a $\mathrm{CO}$ matrix the same transient was formed in high efficiency as was formed in an argon matrix. As 'in cage' recombination of $\mathrm{CO}$ would be expected to be highly efficient in a $\mathrm{CO}$ matrix this indicates that in these complexes this process is hindered.

If the vacant site on a coordinatively unsaturated organometallic transient species is blocked in solution at r.t. the lifetime of the species would be expected to show a very low solvent dependence. The blocked site would prevent the solvent acting as a token ligand as is well established for $(\mathrm{CO})_{5} \mathrm{M}$ (solvent) $(\mathrm{M}=\mathrm{Cr}, \mathrm{Mo}, \mathrm{W})$ and (arene) $\mathrm{M}(\mathrm{CO})_{2}$ (solvent) $(\mathrm{M}=\mathrm{Cr}, \mathrm{Mo})$ in time-resolved studies [28-30]. Measurements of the rate constant for the reaction of transients cis- $(\mathrm{CO})_{4} \mathrm{Cr}$ $\left[\mathrm{C}\left(\mathrm{NR}_{2}\right) \mathrm{R}^{\prime}\right]$ formed from Class 1 complexes with $\mathrm{CO}$ showed that value of the rate constants were remarkably insensitive to the nature of the solvent. Similar behaviour has been observed previously in time-resolved studies on the reaction of $(\mathrm{CO})_{4} \mathrm{MnC}(\mathrm{O}) \mathrm{CH}_{3}$ with $\mathrm{CO}$ and in this study it was proposed that the vacant site on the manganese was blocked [31]. Transient species formed from CO loss of Class 2 complexes show the expected solvent dependence on the rate constant for the reaction of this species with $\mathrm{CO}$. The high sensitivity of the intensity of the low energy band in the absorbance difference spectra of cis $-(\mathrm{CO})_{4} \mathrm{Cr}\left[\mathrm{C}\left(\mathrm{NR}_{2}\right)\right.$ $\mathrm{R}^{\prime}$ ] formed from Class 2 complexes is further evidence that for these transient species a solvent molecule is acting as a token ligand. The lack of sensitivity to solvent in this regard for the transient species form from the Class 1 complexes indicates that a solvent molecule is not ligated to the chromium.

It is possible that the (amino)carbenes are more likely to form coordinatively unsaturated transients with a blocked vacant site than their alkoxy analogues because of steric hindrance on the carbene moiety. One interesting observation from the work carried out by Hafner et al. is that for carbenes containing one heteroatom on the carbene moiety the synthetic activity of the amino carbenes was very sensitive to structural changes, whereas, the (alkoxy) carbenes were much less sensitive [18]. In general it has been observed that all chromium carbenes containing a single alkoxy group on the car- 
bene moiety are active to $\beta$-lactam formation, except those containing a good $\pi$ acceptor ligand on the carbene carbon [1c]. The results from the ${ }^{53} \mathrm{Cr}-\mathrm{NMR}$ study also showed that steric factors were more significant in the amino carbenes. For example, for the (aryl)(dialkylamino) carbenes such as $(\mathrm{CO})_{5} \mathrm{Cr}[\mathrm{C}$ $\left(\mathrm{NMe}_{2}\right) \mathrm{Ph}$ ] studied here, the aryl group is prevented from lying in the plane with the carbene carbon. This is not the case in the alkoxy analogue. Previous studies on bulky carbenes $(\mathrm{CO})_{5} \mathrm{~W}\left[\mathrm{C}\left(\mathrm{NC}_{4} \mathrm{H}_{8}\right) \mathrm{SiPh}_{3}\right]$ and $(\mathrm{CO})_{5} \mathrm{~W}$ $\left[\mathrm{C}(\mathrm{OEt}) \mathrm{SiPh}_{3}\right]$ have shown that the greater amount of steric hindrance in the carbene ligand of the amino carbene can influence both their thermal and photochemistry. While the amino carbene undergoes photoinduced or thermal $\mathrm{CO}$ loss to form a stable complex in which one of the phenyl groups on the silicon blocks the vacant site, no analogous complex is formed from the ethoxy analogue $[11,32]$. Thus the blocking of the chromium centre may simply result as a release in steric strain in the carbene moiety upon loss of a CO. However, electrostatic factors may also play some part in the (alkyl)(amino)carbenes. It is well documented that hydrogen atoms attached to the $\alpha$ carbon in the carbene side chain are remarkably acidic so there may be some electrostatic interaction between the electron rich metal and the hydrogen on the $\alpha$ carbon upon $\mathrm{CO}$ dissociation [33].

Although a relationship between the vacant site being blocked and low synthetic activity of the carbene complex studied holds within the group of complexes studied here, we would like to point out that we are not suggesting that this is a universal explanation for chromium carbene synthetic photo-reactivity. Many other factors such as the electron density on the metal may be important. The electron rich chromium carbenes that contain two heteroatoms are synthetically inactive [18]. The flash photolysis study on one of these $(\mathrm{CO})_{5} \mathrm{Cr}(\mathrm{Im})$ shows evidence for the existence of unsolvated $(\mathrm{CO})_{4} \mathrm{Cr}(\mathrm{Im})$ and suggests that the extremely low propensity of this transient species to bind an incoming solvent molecule is due to the chromium being very electron rich [16]. Moreover, flash photolysis studies only investigate the primary steps of a photochemical reaction and a ketene transient may form further along the reaction pathway. One finding which may be important in relation to this proposal is that in a study by Fischer, a ketene, $\mathrm{Ph}_{2} \mathrm{CCO}$, was formed upon thermolysis of $(\mathrm{CO})_{5} \mathrm{M}[\mathrm{C}(\mathrm{Ph}) \mathrm{Ph}](\mathrm{M}=\mathrm{Cr}, \mathrm{W})$ [34]. Using isotopic labeling and kinetic studies it was shown that the ketene was formed after the complex had lost a CO ligand and that the reaction occurred intramolecularly in the $(\mathrm{CO})_{4} \mathrm{M}[\mathrm{C}(\mathrm{Ph}) \mathrm{Ph}]$ transient. It is possible that a similar photo-induced reaction is taking place in the complexes studied here. Our study on these complexes indicate that secondary photo-products do occur in the matrix studies and such reactions may become impor- tant when a sample is irradiated using a steady state light source as is involved in the synthetic experiments.

\section{Experimental}

\subsection{General methods and materials}

The organometallic complexes were synthesised using literature procedures $[2,35,36]$. The complexes were manipulated under nitrogen using standard Schlenk and high vacuum techniques. The solvents were dried by refluxing over sodium-benzophenone and distilled under a nitrogen atmosphere. The gases used for the matrix experiments are as follows; argon (99.999\% purity) supplied by B.O.C, carbon monoxide (99.97\% purity) and ethene (99.5\% purity) were supplied by Aldrich. Nitrogen (99.9\% purity) and methane (99.99\% purity) were supplied by Linde Gas. Chromium hexacarbonyl, trimethyloxonium tetrafluoroborate, methyllithium, phenyllithium, naphthalene, chlorotrimethylsilane, dimethylformamide, dimethylacetamide, dimethylbenzamide were obtained from Aldrich and used without further purification. Dibenzylformamide and dimethylacetamide were synthesised using an adaptation of the method outlined by Beckwith [37]

\subsection{Spectroscopy}

The IR spectra were recorded on a Nicolet Magna 550 FTIR spectrometer. The spectrometer was continuously purged with $\mathrm{CO}_{2}$ free dry air. The spectra were recorded as the average of 128 scans with $1 \mathrm{~cm}^{-1}$ resolution over the range $4000-400 \mathrm{~cm}^{-1}$. Irradiation in the matrix experiments was carried out using a 1000 W Oriel xenon arc lamp (model 66023). Excess heat was removed with a water filter and wavelengths were selected with cut off filters. The UV-vis were recorded on Unicam-500 UV-vis spectrometer. The matrix isolation and time-resolved apparatus at Maynooth and DCU, respectively has been described in detail elsewhere $[13,29]$. Solutions of the samples for the UV-vis monitored flash photolysis experiments were loaded into a quartz cuvette (10 $\mathrm{mm}$ pathlength) fitted with a Young's high vacuum stockcock and degassing bulb. The samples were degassed by three cycles of freezepump thaw to $10^{-3}$ Torr, followed by a substantial liquid pump to remove traces of water introduced in the degassing procedure. The samples were back-filled to 760 Torr with the appropriate gas. The absorbances of the samples were typically 1.0 at $355 \mathrm{~nm}$.

\section{Acknowledgements}

We are very grateful to Dr Conor Long for use of the equipment at Dublin City University and for useful 
discussions. We are also grateful to Dr J. McCaffrey and Dr V. Bracken who built the matrix rig at Maynooth. We thank Donegal County Council and the Irish American Partnership for a grant to M.L.G. and Offaly County Council and Enterprise Ireland for a grant to K.O.D.

\section{References}

[1] (a) K.H. Dötz, P. Tomuschat, Chem. Soc. Rev. 28 (1999) 187. (b) L.S. Hegedus, Acc. Chem. Res. 28 (1995) 299. (c) L.S. Hegedus, Tetrahedron 53 (1997) 4105.

[2] L.S. Hegedus, M.A. Schwindt, S. De Lombaert, R. Imwinkelried, J. Am. Chem. Soc. 112 (1990) 2264.

[3] J. Zhu, C. Deur, L.S. Hegedus, J. Org. Chem. 62 (1997) 7704.

[4] L.S. Hegedus, Pure Appl. Chem. 55 (1983) 1745

[5] L.S. Hegedus, G. de Weck, S. D’Andrea, J. Am. Chem. Soc. 110 (1988) 2122.

[6] (a) S. Köbbing, J. Mattay, G. Raabe, Chem. Ber. 126 (1993) 1849. (b) S. Köbbing, J. Mattay, Tetrahedron Lett. 33 (1992) 927.

[7] L.S. Hegedus, J. Montgomery, Y. Narukawa, D.C. Snustad, J. Am. Chem. Soc. 113 (1991) 5784.

[8] L.K. Fong, N.J. Cooper, J. Am. Chem. Soc. 106 (1984) 2595.

[9] H.C. Foley, L.M. Strubinger, T.S. Targos, G.L. Geoffroy, J. Am. Chem. Soc. 105 (1983) 3064.

[10] P.C. Servaas, D.J. Stufkens, A. Oskam, J. Organomet. Chem. 390 (1990) 61.

[11] A.D. Rooney, J.J. McGarvey, K.C. Gordon, R.A. McNicholl, U. Schubert, W. Hepp, Organometallics 12 (1993) 1277.

[12] A.D. Rooney, J.J. McGarvey, K.C. Gordon, Organometallics 14 (1995) 107.

[13] M.L. Gallagher, J.B. Greene, A.D. Rooney, Organometallics 16 (1997) 5260.

[14] A. Rosa, G. Ricciardi, E.J. Baerends, D.J. Stukens, J. Phys. Chem. 100 (1996) 15346.
[15] C. Pollak, A. Rosa, E.J. Baerends, J. Am. Chem. Soc. 119 (1997) 7324.

[16] S. Oishi, K. Tokumaru, J. Phy. Org. Chem. 2 (1989) 323.

[17] C. Borel, L.S. Hegedus, J. Krebs, Y. Satoh, J. Am. Chem. Soc. 109 (1987) 1101.

[18] A. Hafner, L.S. Hegedus, G. deWeck, B. Hawkins, K.H. Dötz, J. Am. Chem. Soc. 110 (1988) 8413.

[19] E.O. Fischer, H. Fischer, Chem. Ber. 107 (1974) 657.

[20] R.S. Sheridan, R.A. Moss, B.K. Wilk, S. Shen, M. Wlostowski, M.A. Kesselmayer, R. Subramanian, G. Kmiecik-Lawrynowicz, K. Krogh-Jespersen, J. Am. Chem. Soc. 110 (1988) 7563.

[21] J.M. Kelly, D.V. Bent, H. Hermann, D. Schulte-Frohlinde, E.K. Von Gustorf, J. Organomet. Chem. 69 (1974) 259.

[22] J.M. Kelly, C. Long, R. Bonneau, J. Phys. Chem. 87 (1983) 3344.

[23] S.P. Church, F.W. Grevels, H. Hermann, K. Schaffner, Inorg. Chem. 24 (1985) 418.

[24] H. Hermann, F.W. Grevels, A. Henne, K. Schaffner, J. Phys. Chem. 86 (1982) 5151

[25] X. Xie, J.D. Simon, J. Phys. Chem. 93 (1989) 4401.

[26] G.L. Geoffroy, S.L. Bassner, Adv. Organomet. Chem. 28 (1988) 1.

[27] L.S. Hegedus, R. Imwinkelried, M. Alarid-Sargent, D. Dvorak, Y. Satoh, J. Am. Chem. Soc. 112 (1990) 1109.

[28] G.R. Dobson, P.M. Hodges, M.A. Healy, J.J. Turner, S. Firth, K.J. Asali, J. Am. Chem. Soc. 109 (1987) 4218.

[29] B.S. Creaven, M.W. George, A.G. Ginzburg, C. Hughes, J.M. Kelly, C. Long, I.M. McGrath, M.T. Pryce, Organometallics 12 (1993) 3127.

[30] C.J. Breheny, J.M. Kelly, C. Long, S. O'Keefe, M.T. Pryce, G. Russell, M.M. Walsh, Organometallics 17 (1998) 3690.

[31] K. McFarlane, B. Lee, J. Bridgewater, P.C. Ford, J. Organomet. Chem. 554 (1998) 49.

[32] (a) U. Schubert, W. Hepp, J. Muller, Organometallics 5 (1986) 173. (b) U. Schubert, J. Organomet. Chem. 358 (1988) 215.

[33] C.G. Kreiter, Angew. Chem. Int. Ed. Engl. 7 (1968) 390

[34] H. Fischer, Angew. Chem. Int. Ed. Engl. 22 (1983) 874

[35] U. Klabunde, E.O. Fischer, J. Am. Chem. Soc. 26 (1967) 7141.

[36] R. Imwinkerlried, L.S. Hegedus, Organometallics 7 (1988) 702.

[37] A.L.J. Beckwith, J. Zabicky, The Chemistry on Amides, Interscience, New York, 1970, p. 73. 